\title{
Optimal Control of Pantograph-Catenary System Based on Parametric Identification
}

\author{
Aleksandrs Matvejevs ${ }^{1}$, Andrejs Matvejevs ${ }^{2},{ }^{1-2}$ Riga Technical University
}

\begin{abstract}
This article continues research on the pantographcatenary system started in the previous papers [1], [2].

The main purpose of the study is to use a computer of highspeed train to optimize the pantograph-catenary system by reducing power consumption when basic parameters of pantograph and catenary (contact network) change over time randomly.

A linear model of pantograph-catenary system is considered where the upper and lower blocks of pantograph and catenary are modelled using lumped masses, springs and shock absorbers.

The input and output system signals are measured when the train moves. These signals are processed by parametric identification algorithms to determine current values of system matrices. State matrices are used in Riccati equation to calculate controller coefficients. Adaptive controller provides dynamic stability of the system when its parameters change over time, and the system is subject to random external perturbations.
\end{abstract}

Keywords - Pantograph-catenary system, mechanical multibody system, parametric identification, controller, adaptive pantograph

\section{INTRODUCTION}

Since October 1964, when the first high-speed railway line allowed for a speed of $210 \mathrm{~km} / \mathrm{h}$ was commissioned in Japan, nearly 50 years have passed. Many of high-speed rail problems have been resolved successfully during this time period. In the coming years, experts from leading industrialized countries (Japan, France and others) plan to increase train speed to $500 \mathrm{~km} / \mathrm{h}$. At the same time scientists have identified those problems that need to be addressed to further enhance progress in this area [6]. In the following block diagram (Fig1.), the solution to these problems will be investigated by computer modelling. As can be seen from the structure, one of the main problems is the study of models with time-varying parameters of the main components of this high-speed rail system.

This paper considers some results of dynamic characteristics of the aforementioned block-scheme components with time-changing parameters, pantograph and catenary.

In contrast to the previously published results on pantograph-catenary system [5], [7] - [12], we present results on the system with optimal control methods based on parameter identification and adaptive control algorithms. These methods of dynamic systems were investigated by the authors for various purposes [1] - [4].

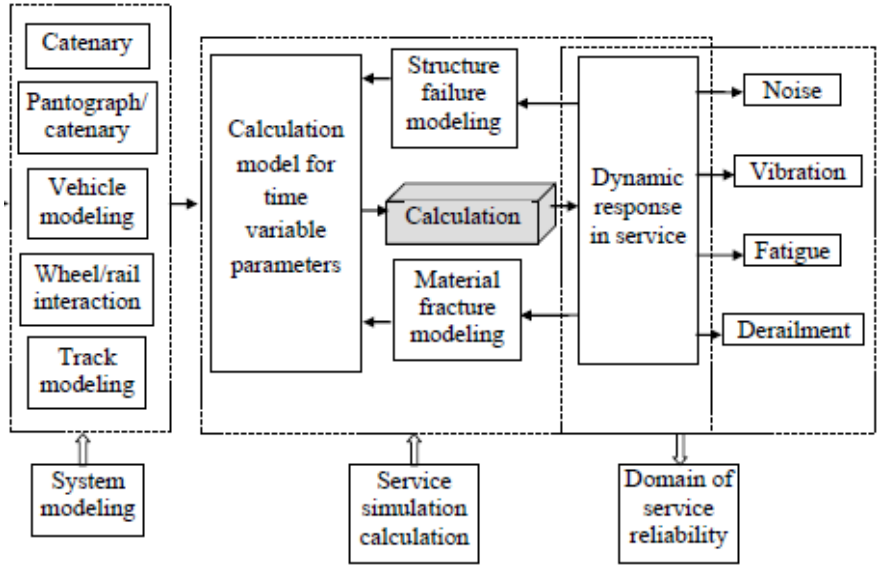

Fig. 1. Computer simulation of service reliability for high-speed trains

In the study, parameters of pantograph-catenary model vary randomly over time, and the system is periodically subjected to external perturbations.

The recorded input and output signals of the system, during its functioning in real time, provide information about system states. These signals are processed using parametric identification algorithms, which include the following main tasks:

- measurement of input and output signals of the system in a given time interval;

- calculation of state vector of pantograph model;

- calculation of parameter current values of the system mathematical model;

- calculation of active pantograph controller parameters for every time interval where the state vector of pantograph and the mathematical model parameters are calculated;

- correction of pantograph controller coefficients when the model parameters and the state vector change in a given time interval.

Solutions to parametric identification problem for the system by means of pantograph state vector allow one to calculate coefficients of adaptive controller based on Riccati equation [2]. An adaptive controller created on these principles guarantees optimal dynamic characteristics of pantograph-catenary system both in case of parameter random changes over time and in case of external disturbances (drums) on the system.

Based on the Matlab/Simulink simulation, results of the developed control algorithms for pantograph-catenary system with time-varying parameters confirm effectiveness of the system compared to other methods of solving the problem using, for example, a second-order sliding mode control scheme [5]. 
II. MATHEMATICAL MODEL OF THE SYSTEM WITH VARYING PARAMETERS

\section{A. Catenary Mathematical Model with Time-varying} Parameters

Catenary mathematical model is usually represented by the 2nd order differential equation with time-varying parameters [2], [4]:

$$
M_{i}(t) \ddot{z}_{i}(t)+C_{i}(t) \dot{z}_{i}(t)+K_{i}(t) z_{i}(t)=Q_{i}(t),
$$

where

$z_{i}(t)$ - amplitude of the $i$-th modal component,

$M_{i}(t)$ - mass of the $i$-th modal component,

$C_{i}(t)$-damping coefficient of the $i$-th modal component,

$K_{i}(t)$-stiffness coefficient of the $i$-th modal component,

$Q_{i}(t)$ - forcing function of the $i$-th modal component.

Taking the frequency of oscillations for the $i$-th component of the model by $\omega_{i}(t) \quad\left(\omega_{i}(t)=\sqrt{\frac{K_{i}(t)}{M_{i}(t)}}\right)$, and the damping factor with respect to other model parameters by $\varepsilon_{i}(t)$, Equation (1.1) takes the form [1]:

$M_{i}(t) \ddot{z}_{i}(t)+2 M_{i}(t) \varepsilon_{i}(t) \dot{z}_{i}(t)+M_{i}(t) \omega_{i}^{2}(t) z_{i}(t)=Q_{i}(t)$,

For a given shape and vibration frequency of catenary signals, time response for every component is defined by (1.2), and the output signal of the entire catenary model is equal to the sum of all $M_{i}(t)$ components.

\section{B. Pantograph Mathematical Model with Variable Parameters}

A mathematical model of passive pantograph is defined by 2nd order differential equation with time-varying parameters [1]:

$m(t) \ddot{y}_{p}(t)=-F_{c}(t)-w(t)\left(y_{p}(t)-y_{f}(t)\right)-u(t)\left(\dot{y}_{p}(t)-\dot{y}_{f}(t)\right)$, $M(t) \ddot{y}_{f}(t)=F_{s}(t)+w(t)\left(y_{p}(t)-y_{f}(t)\right)+u(t)\left(\dot{y}_{p}(t)-\dot{y}_{f}(t)\right)-$ $v\left(\dot{y}_{f}(t)-\dot{y}_{r}(t)\right)-t_{m}\left(y_{f}(t)-y_{r}(t)\right)$,

where

$y_{p}(t)$ - displacement of the head,

$y_{f}(t)$ - displacement of the frame,

$y_{r}(t)$ - displacement of the vehicle roof,

$F_{c}(t)$ - contact force acting on the pantograph head,
$F_{s}(t)$ - permanent lifting of static force.

Assuming equation (1.3) with constant coefficients $m, M$, $w$, and $u$, Laplace Transform can be applied with zero initial conditions for $Y_{p}, Y_{f}$, and $F_{c}$. As a result, we receive

$$
\begin{aligned}
\left(m s^{2}+u s+w\right) Y_{p}+F_{c} & =(u s+w) Y_{f}, \\
\left(M s^{2}+(u+v) s+\left(w+t_{m}\right)\right) Y_{f} & =(u s+w) Y_{p}
\end{aligned}
$$

According to (1.4), transfer function of the pantograph can be found. Evaluating $Y_{p} / X_{0}$ and $Y_{f} / X_{0}$ we obtain

$$
\begin{gathered}
\frac{Y_{p}(s)}{X_{0}(s)}=\frac{M s^{2}+(u+v) s+w+t_{m}}{\Delta} K_{w} \\
\frac{Y_{f}(s)}{X_{0}(s)}=\frac{u s+w}{\Delta} K_{w},
\end{gathered}
$$

where

$$
\begin{aligned}
& \Delta=M m s^{4}+(M u+m(u+v)) s^{3}+ \\
& \left(M\left(w+K_{w}\right)+m\left(w+t_{m}\right)+u(u+v)-u^{2}\right) s^{2}+ \\
& \left((u+v)\left(w+K_{w}\right)+u\left(w+t_{m}\right)-2 u w\right) s+ \\
& \left(\left(w+t_{m}\right)\left(w+K_{w}\right)-w^{2}\right) .
\end{aligned}
$$

This model (1.5) and (1.6) of two-mass system is a system of two degrees of freedom [1]. Although the actual pantograph is much more complicated, this model is sufficient to represent dynamic characteristics of the pantograph system with two degrees of freedom.

To analyse pantograph dynamic characteristics, specific (nominal) parameters of passive pantograph should be used. A block diagram of passive pantograph is shown in [1]; the parameters for this version are as follows:

$K_{w}=178.58 \mathrm{~kg} / \mathrm{m}, w=178.59 \mathrm{~kg} / \mathrm{m}, u=3.57 \mathrm{~kg} \cdot \mathrm{sec} / \mathrm{m}$, $t=34287.3 \mathrm{~kg} / \mathrm{m}, v=21.43 \mathrm{~kg} \cdot \mathrm{sec} / m, m=1.11 \mathrm{~kg} \cdot \mathrm{sec}^{2} / \mathrm{m}$, $M=1.66 \mathrm{~kg} \cdot \mathrm{sec}^{2} / \mathrm{m}$.

Further analysis of the system provides a pantograph with one degree of freedom defined by the following transfer function (1.5):

$H_{p x}(s)=\frac{Y_{p}(s)}{X_{0}(s)}=\frac{161.3 s^{2}+2428 s+3.35 \cdot 10^{6}}{s^{4}+18.28 s^{3}+20794 s^{2}+66231 s-17341}$

\section{System "Pantograph-Catenary" Model with Variable Parameters}

System software MATLAB/Simulink allows us to simulate dynamic systems with time-varying parameters. We illustrate 
this by an example of catenary dynamic characteristics with time-varying parameter modeling by (1.2).

This simulation includes the following steps:

a) representation of the system model with timevarying parameters to the model with constant parameters;

b) formation of the transfer function for the system with given (nominal) values of the coefficients $(M, C, K, Q)$ in (1.1);

c) formation of the corresponding $\mathrm{S}$-function in MATLAB / Simulink based on the original transfer function, which allows changing of the coefficients over time in the desired range of frequencies and amplitudes;

d) adding necessary subfunctions of random variations in amplitudes of the simulated output signal to the S-function;

e) studying the dynamic system under external disturbances at different time intervals of operation.

f) creating the combined pantograph-catenary system with time-varying parameters.

The research block-scheme of the catenary dynamic model with time-varying parameters is shown in Fig. 1a. The transfer function (TF) of the catenary (upper photo in Fig.1a) and TF of the pantograph (bottom photo in Fig.1a) are represented. From the graphics in Fig.1b one can conclude that both devices are unstable. The model of output signals with two options of time-varying parameters is shown in Fig. $2 \mathrm{~b}$.

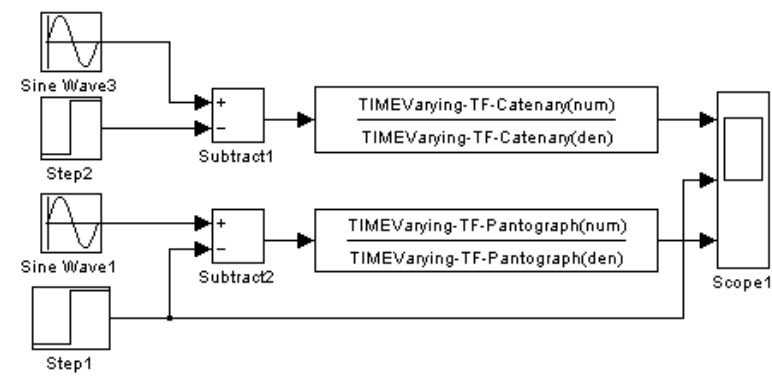

Fig. 1a. Schemes of the pantograph and catenary models

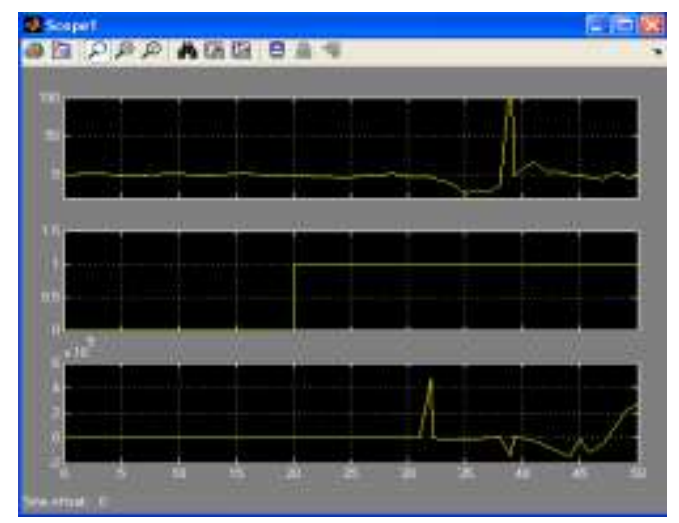

Fig. 1b. Transient response of the catenary (upper), transient response of the pantograph (bottom)
Similarly, dynamic model of passive pantograph with timevarying parameters was developed (Fig. 2a).

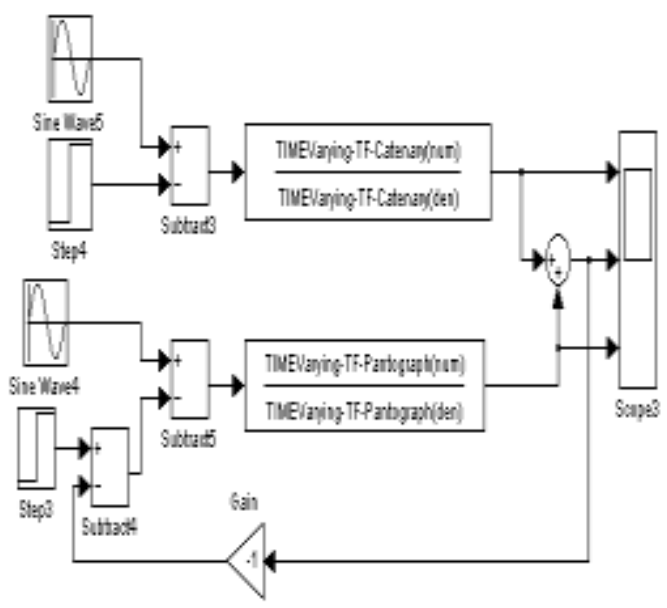

Fig. 2a. Scheme of the pantograph-catenary system

The transient response of the catenary (upper photo in the Fig. 2b) and the transient response of the pantograph (bottom photo in the Fig. 2b) are represented.

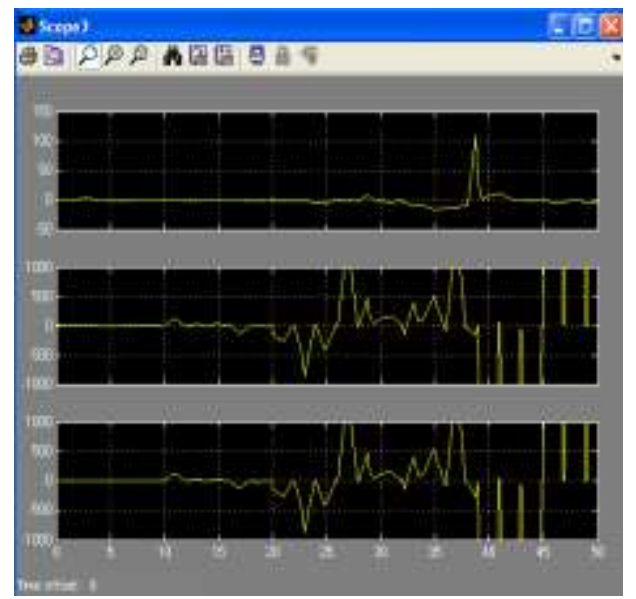

Fig. 2b. Transient response of the system (midlle), of the catenary (upper), of the pantograph (bottom)

In the middle photo the transient response of the whole system is shown. It can be concluded that this system is unstable, too.

Dynamic model of the pantograph-catenary system with time-varying parameters with a controller (active pantograph) is shown in Fig. 3a. The transient response of this system with a controller (Transfer Fun1) without changing its parameters is shown in Fig. 3b. As can be seen from Fig. 3b, this system is also unstable. 


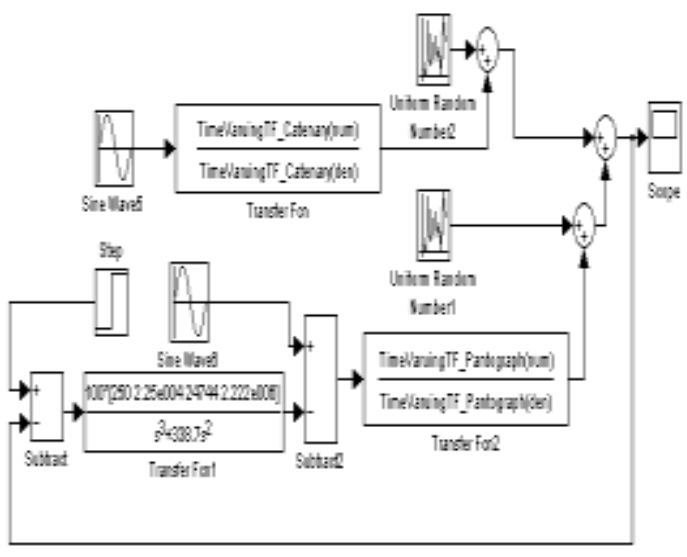

Fig. 3a. Scheme of the system with controller (active pantograph)

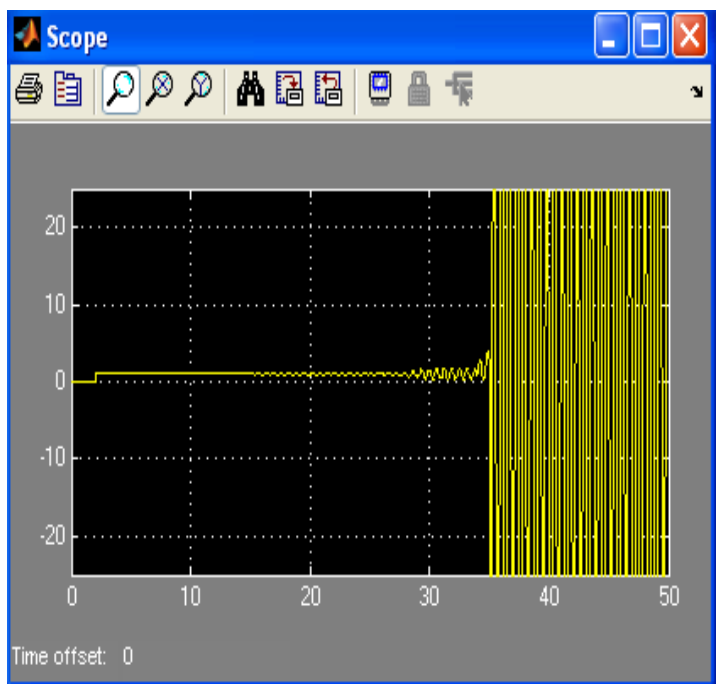

Fig. 3b. Transient response of the system with controller with constant parameters

Plots of the transient responses of the system with the three types of changing rate of the parameters as a function of time are shown in Fig. 4a,b,c. At a low rate of change of parameters, the system loses its steady state already at 15 seconds (Fig.4a). At the increased rate of change of the parameters, the loss of stability occurs more rapidly (Fig. 4b, at $7 \mathrm{sec}$.). At even higher rates of parameter change, buckling occurs at 3 seconds (Fig.4c). At certain ratios of time-varying system parameters, the resonant vibration processes are discovered.

\section{III. "PANTOGRAPH- CATENARY" SYSTEM BASED ON} PARAMETRIC IDENTIFICATION AND ADAPTIVE CONTROL
Simulation results of pantograph-catenary system with time-varying parameters which contains a controller with constant parameters in the control loop confirm that this system does not have the required stability.

To provide required dynamic characteristics of the system in its real driving conditions in electric systems, adaptive controller algorithms have been developed based on parametric identification methods to estimate current values of the system parameters. Based on the model estimated parameters and current values of state vector, controller coefficients are calculated, which guarantee the required dynamic characteristics of the system in each input and/or output time interval.

A block diagram of the pantograph-catenary model with time-varying parameters containing an adaptive controller is shown in Fig. 5.

Blocks that calculate adaptive controller coefficients are depicted in the lower part of the scheme:

1) memory 1 , memory 2 - to check system input and output signals;

2) Matrix Concatenate - to calculate system matrices in state space and matrices of Riccati equation;

3) Logical Operator 1 - to calculate matrices in state space based on pantograph state vector;

4) $\mathrm{K}_{\mathrm{lqr}}$ - to calculate vector of current values of the system adaptive controller;

5) Environment Controller - to prepare adaptive controller algorithm.
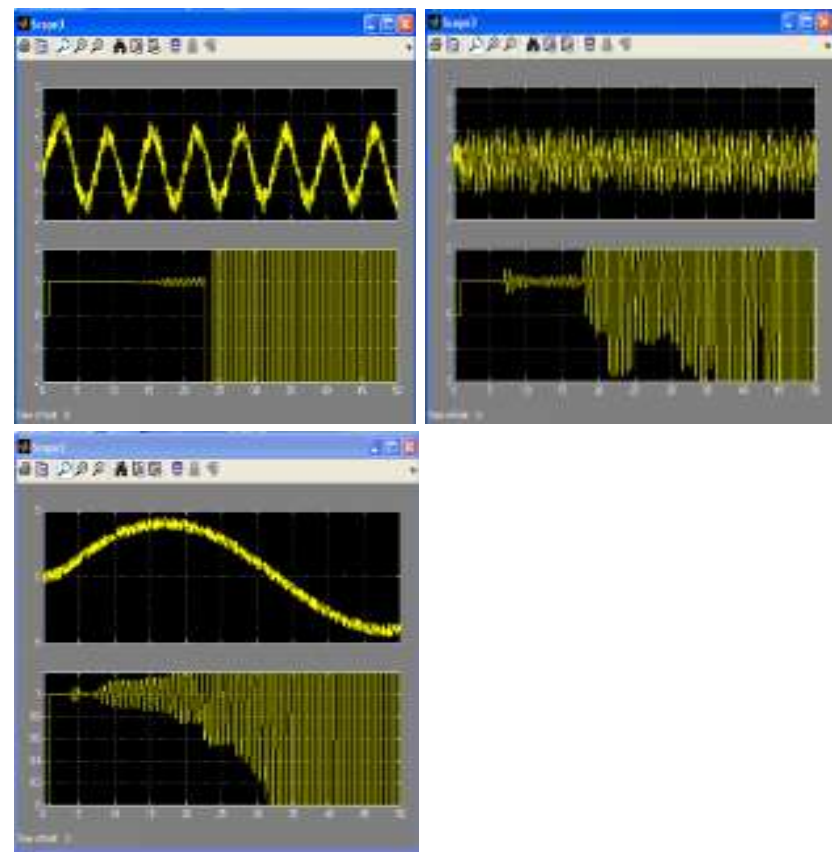

Fig. 4a,b,c. Transient responses of the system (bottom) for 3-d velocities of parameters over time(upper) 


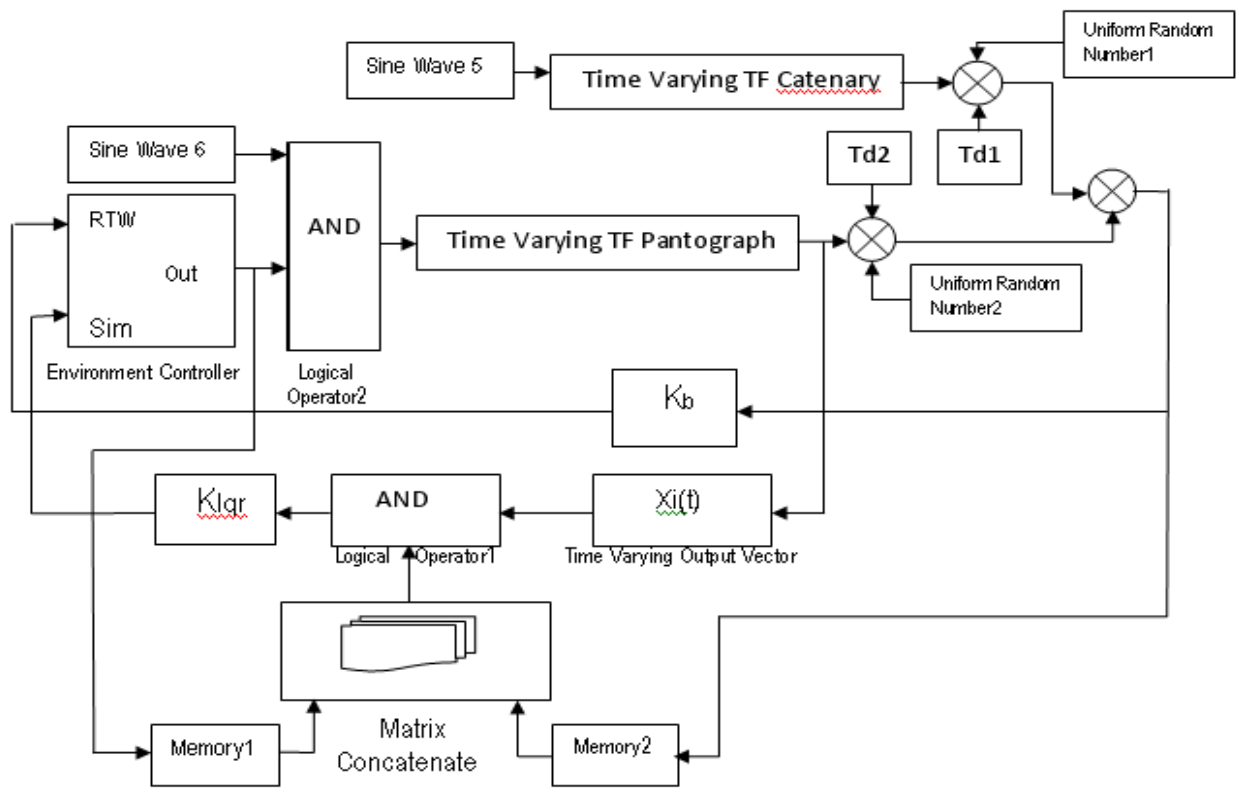

Fig. 5. Scheme of the pantograph-catenary model with adaptive controller

To evaluate dynamic characteristics of the pantographcatenary system, whose block diagram is shown in Fig. 5, a special program "ADAPPANCAT" in MATLAB was developed, which implemented all the above-mentioned algorithms for the system with time-varying parameters where various external (shock) perturbations impact the system simultaneously. (Footnotes explain the use of functions and parameters).

The following conclusions can be made based on the study of different examples of pantograph-catenary model with time-varying parameters:

1) Simulation results show effectiveness of the controller adaptive settings $\left(\mathrm{K}_{\mathrm{lqr}}\right)$ along with random variations of the pantograph-catenary model parameters, as well as random external (shock) perturbations acting in the system.

2) Transient response of pantograph-catenary system, as well as system response to external shock perturbation (shown in Fig.6) confirms high efficiency of pantographcatenary adaptive system.

3) BODE diagram of pantograph-catenary adaptive system demonstrates that the system operates steadily at time changing random parameters (Fig. 7).

4) Adaptive controller effective response to random variations of system parameters and external perturbations should also be mentioned. Table 1 shows controller coefficients for 10 consecutive cycles of random system parameters and random shock perturbations. (External pressure is specified in Newtons at a nominal value of $\mathrm{Td} 1=$ 3.1N).

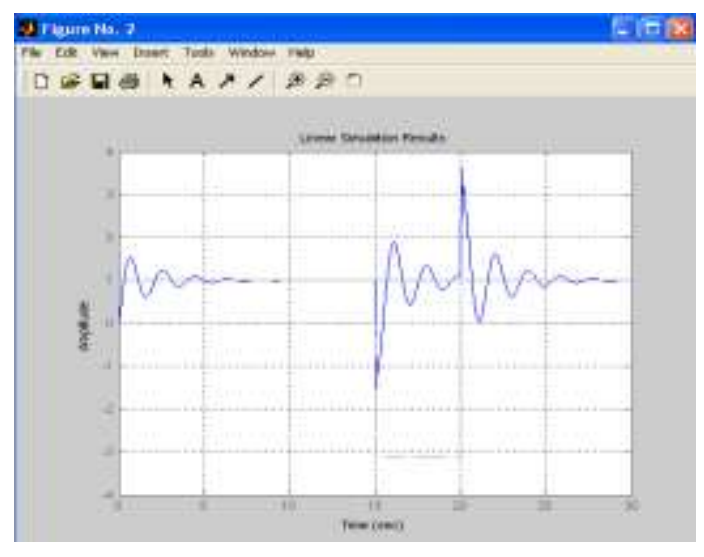

Fig. 6. Plot(t,u,'r',t,Td1,'r'); 1sim(cl_lqr,u,t)

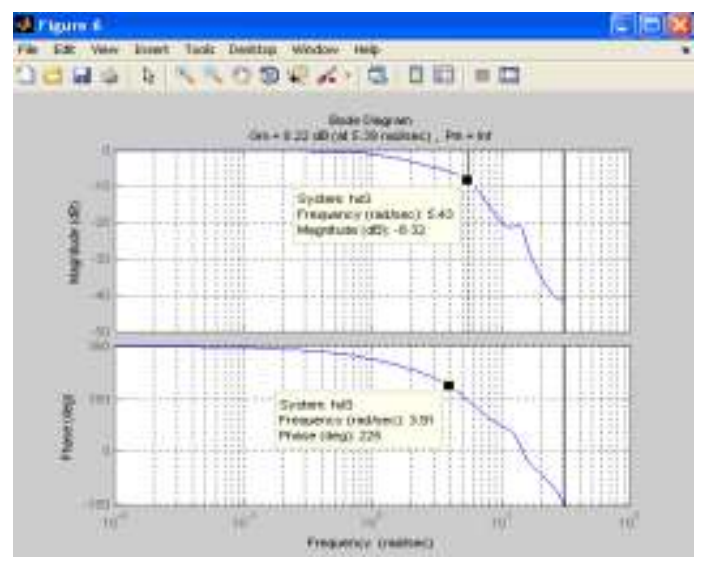

Fig. 7. Margin 1sim(cl_lqr,u,t) 
TABLE I

CONTROLLER COEFFICIENTS FOR 10 DIFFERENT VALUES OF SYSTEM PARAMETERS AND EXTERNAL ForCE TD1

\begin{tabular}{|c|c|c|c|c|c|c|c|}
\hline lound & Function & \multicolumn{5}{|c|}{ Coefficient's values in $i$-th round of calculations } & Td1 \\
\hline 1 & K_lqr' & {$[44.7214$} & 1.7127 & 9.7904 & 25.6275 & $100.4836137 .3634]$ & -12.3566 \\
\hline 2 & K_lqr2 & {$[44.7214$} & 1.9140 & 9.9172 & 25.3894 & $48.3065144 .4489]$ & -8.9054 \\
\hline 3 & K_lqr3 & {$\left[\begin{array}{ll}44.7214 & 3.6587\end{array}\right.$} & 2.1938 & 10.0973 & 29.5113 & $79.2822106 .2715]$ & -36.0669 \\
\hline 4 & K_lqr4 & {$[44.7214$} & 1.9056 & 9.9774 & 27.3275 & $120.9058146 .8093]$ & -39.2068 \\
\hline 5 & K_lq15 & {$[44.7214$} & 1.9486 & 10.0315 & 30.5245 & 84.5308 140.1249] & -56.4442 \\
\hline 6 & K_lar6 & {$[44.7214$} & 1.3642 & 5.2435 & 16.6799 & 107.1087 75.7185] & -22.7472 \\
\hline 7 & K_lgr 7 & {$[44.7214$} & 2.2341 & 10.1712 & 29.3525 & $78.9103178 .3005]$ & -76.4752 \\
\hline 8 & K_lqp8 & {$[44.7214$} & 2.4193 & 10.4142 & 36.1082 & 121.4122 172.8915] & -29.6197 \\
\hline 9 & K_lqr9 & {$[44.7214$} & 2.5170 & 10.6846 & 34.1508 & $98.1926103 .3616]$ & -43.9041 \\
\hline 10 & K_lqr10 & {$\left[\begin{array}{ll}44.7214 & 3.5404\end{array}\right.$} & 1.6466 & 5.4825 & 22.5220 & $99.6028 \quad 70.1200]$ & -89.3966 \\
\hline
\end{tabular}

\section{CONCLUSIONS}

Mathematical models of pantograph-catenary adaptive system whose parameters vary randomly over time and the system affected by external shock disturbance led to the following conclusions:

a) the model adequately reflects dynamic characteristics of real pantograph-catenary autonomous systems used in modern electric trains moving at high speeds $(200 \mathrm{~km} / \mathrm{h}$ and more $)$;

b) evaluation of time-varying system parameters should be done in real time based on measurement data of system input and output and further implementation in parameter identification algorithms (using the pantograph computing device);

c) based on estimates of current values of system parameters (obtained by solving the parametric identification problem), optimal values of controller coefficients are calculated using Riccati equation;

d) system adaptive controller provides the necessary dynamic and accuracy characteristics of the system with random changes in system parameters and external shock impacts during the operation;

e) elaborated programs, which implement basic algorithms of measurement data, parametric identification and adaptive corrector, do not impose special requirements on the pantograph computer in a train.

\section{REFERENCES}

[1] Matvejevs Al., Matvejevs An., Pantograph-Catenary System Modeling Using MATLAB-Simulink Algorithms. Scientific Journal of Riga Technical University, Vol.5, No.44, Riga-2010, pp.38-43 https:/ortus.rtu.lv/science/en/publications/8849

[2] Matvejevs Al., Matvejevs An., Adaptive Control of Electric Solar Sail Based on Parametric Identification. Scientific Proceedings of Riga Technical University, Vol.5, No.36, Riga-2008, pp.10-18.
[3] Matvejevs Al., Matvejevs An. and Vulfs G. Time-optimal Adaptive Control of Dynamic Systems Based on Parametric Identification. Scientific Proceedings of Riga Technical University, Riga, Vol.5, No 31, 2007, pp. 89-96

[4] Matvejevs Al, Matvejevs An., Vulfs G. Adaptive Control of Dynamic Systems Based on Parametric Identification. Scientific Proceeding of Riga Technical University, Vol.5, No.28, Riga, 2006, 41-50.

[5] Pisano, A., Usai, E. Contact force estimation and regulation in active pantograph: an algebraic observability approach. Asian Journal of Control, Vol.12, No. 5, pp. 575-666, 2010.

[6] ZHANG ShuGuang, ZHANG WeiHua and JIN XueSong. Dynamics of high speed wheel/rail system and its modelling. Chinese Science Bulletin. June 2007. vol. 52. no. 11. 1566-1575.

[7] Tiago Manuel Oliveira Valezim Teixeira. Dynamics and Control of a High Speed Train Pantograph System (Disserta, $\mathrm{c}^{\sim}$ ao para obten, $\mathrm{c}^{\sim}$ ao do Grau de Mestre em Engenharia Mec^anica). Setembro - 2007

[8] Kumaniecka A., Snamina J. Dynamics of the Catenary Modelled by a Periodical Structure. Journal of Theoretical and Applied Mechanics, 46,4, pp. 869-878, Warsaw 2008.

[9] Benedetto Allotta, Alessandro Pisano, Luca Pugi, Elio Usai. Variable Structure Control (VSC) of a servo-actuated ATR90-type pantograph. Proceedings of the 44th IEEE Conference on Decision and Control, 2005, Seville, pp.590-595.

[10] O'Connor, D. Modelling and simulation of pantograph-catenary systems Master of Science in Mechanical Engineering. MIT, 1984

[11] Gilbert, G., Davies, H.E.H. "Pantograph Motion on a Nearly Uniform Railway Overhead Line, "Proceedings of the IEEE, Vol. $113, p .485,1966$

[12] Armbruster K. Modeling and Dynamics of Pantograph-Catenary Systems for High- speed Trains. Masters of Science in Mechanical Engineering at the MIT, May 1983.

Aleksandrs Matvejevs graduated from Riga Technical University, Faculty of Automation and Computing Technique. He received Doctoral degree in 1991 and became an Associate Professor at Riga Technical University in 1999. Aleksandrs Matvejevs is a Doctor of Mathematics (specializing in number theory with applications, mathematical modelling and parameter estimation with the method of associative modelling). He is the author of about 30 scientific publications and conference papers. 
Andrejs Matvejevs graduated from Riga Technical University, Faculty of Automation and Computing Technique. He received Doctoral degree in 1989 and became an Associate Professor at Riga Technical University in 2000 and a Full Professor in 2005. He has made the most significant contribution to the field of actuarial mathematics. Andrejs Matvejevs is a Doctor of Technical Sciences in information systems. Until 2009 he was a chief actuary at the insurance company "BALVA". For more than 25 years he has taught at Riga Technical University and Riga International College of Business Administration, Latvia. His previous research was devoted to solving dynamical systems with random perturbation. His current professional research interests include applications of Markov chains to actuarial technologies: mathematics of finance and security portfolio.

$\mathrm{He}$ is the author of about 40 scientific publications, two study books and numerous conference papers.

Aleksandrs Matvejevs, Andrejs Matvejevs. Sistēmas „pantogrāfs - strāvas uztvērējs” optimālā vadība ar parametriskas identifikācijas metodēm

Šajā darbā tiek apkopoti sistēmas ,pantogrāfs - strāvas uztvērējs” pētī̌sanas rezultāti, kas ir iepriekšējā raksta turpinājums. Šì pētījuma galvenais mērķis bija ātrvilciena datora ciešā izmantošana sistēmas ,pantogrāfs - strāvas uztvērējs” funkciju optimizācijai, lai samazinātu enerğijas patēriṇu pantogrāfa un strāvas uztvērēja pamatparametru izmainas laikā.

Tiek aplūkots sistēmas „pantogrāfs - strāvas uztvērējs” lineārais modelis, kurā pantogrāfa un kontaktu tīkla augšējais un apakšejais bloki tiek veidoti, n̦emot vērā sadalītās masas, atsperes un amortizatorus, kuras parametri mainās nejauši. Šīs sistēmas īpašā nozīme saistīta ar to, ka ātrvilciena kustības gadījumā notiek ieejas un izejas signālu mērījumi un, pamatojoties uz šo signālu pārstrādi ar speciālo parametru identifikācijas algoritmu, tiek veidots pantogrāfa kontrollera algoritms. Pamatojoties uz pašreizējo vērtību sistēmas parametru novērtējumiem, aprēķina kontrollera koeficientu optimālās vērtības, izmantojot Rikati vienādojumu. Sistēmas adaptīvais kontrollers nodrošina nepieciešamās dinamiskās īpašības sistēmas parametru nejaušas izmaiṇas brī̌zu un ārējo traucējumu gadījumos. Izstrādātās programmas, kuras īsteno mērījumu informācijas algoritmu, kā arī parametriskās identifikācijas un adaptīvā kontrollera algoritmu, neizvirza jaunas prasības elektrovilcienu pantogrāfa skaitļošanas kompleksam.

Александр Матвеев, Андрей Матвеев. Оптимальное управление системой «пантограф-токоприемник» с использованием параметрической идентификации

В статье излагаются результаты исследования системы «пантограф-токоприемник» как продолжение предыдущей работы. Основная цель проведенного исследования состояла в том, чтобы максимально использовать компьютер скоростного электропоезда для оптимизации функционирования системы «пантограф-токоприемник» с целью уменьшения расхода электроэнергии при случайном изменении основных параметров пантографа и токоприемника во времени.

Рассматривается линейная модель системы «пантограф-токоприемник», где верхний и нижний блоки пантографа, а также токоприемника, моделируются с учетом сосредоточенных масс, пружин и амортизаторов, параметры которых изменяются во времени случайным образом. Особенность построения этой системы заключается в том, что при движении поезда осуществляется измерение входных и выходных сигналов системы и на основании обработки этих сигналов с использованием специальных алгоритмов параметрической идентификации формируется алгоритм контроллера пантографа. На основе оценок текущих значений параметров системы вычисляются оптимальные значения коэффициентов контроллера пантографа с использованием уравнения Риккати. Адаптивный контроллер системы обеспечивает требуемые динамические характеристики системы при случайных изменениях параметров системы и внешних ударных воздействиях при ее функционировании. Разработанные программы, реализующие основные алгоритмы обработки измерительной информации, параметрической идентификации и адаптивного контроллера не предъявляют новых требований к вычислительному комплексу пантографа электропоезда. 